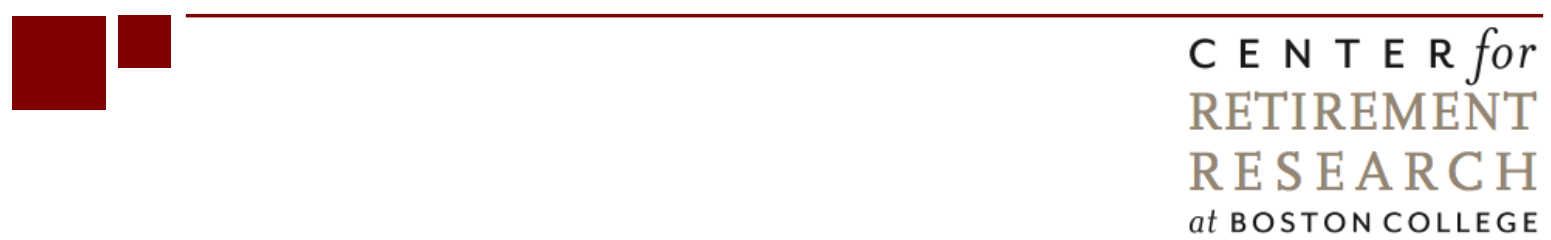

\title{
RESIDENTS IN SENIORS HOUSING AND CARE COMMUNITIES: OVERVIEW OF THE RESIDENTS FINANCIAL SURVEY
}

\author{
Norma B. Coe and April Yanyuan Wu \\ CRR WP 2012-6 \\ Date Released: April 2012 \\ Date Submitted: November 2011 \\ Center for Retirement Research at Boston College \\ Hovey House \\ 140 Commonwealth Avenue \\ Chestnut Hill, MA 02467 \\ Tel: 617-552-1762 Fax: 617-552-0191 \\ http://crr.bc.edu
}

Norma B. Coe is associate director for research at the Center for Retirement Research at Boston College (CRR). April Yanyuan Wu is a research economist at the CRR. The research reported here was performed pursuant to a grant from the National Investment Center for the Seniors Housing \& Care Industry (NIC), the Assisted Living Federation of America (ALFA), and the American Seniors Housing Association (ASHA). The opinions and conclusion expressed are solely those of the authors and do not represent the opinions or policy of NIC, ALFA, ASHA, or Boston College. The authors are grateful for comments supplied on an earlier draft by Charles Harry. They would also like to thank the team at ProMatura Group, LLC, especially Edie Smith and Margaret Wylde, and Mashfiqur Khan, Madeline Medenica and Zhenya Karamcheva for research assistance. All errors are their own.

Corresponding author: Norma B. Coe, Center for Retirement Research at Boston College, Hovey House, 258 Hammond St., Chestnut Hill, MA 02467; Tel: (617) 552-1762;

Fax: (617) 552-0191; e-mail: Norma.Coe@bc.edu

(C) 2012, Norma B. Coe and April Yanyuan Wu. All rights reserved. Short sections of text, not to exceed two paragraphs, may be quoted without explicit permission provided that full credit, including (C) notice, is given to the source. 


\title{
About the Center for Retirement Research
}

The Center for Retirement Research at Boston College, part of a consortium that includes parallel centers at the University of Michigan and the National Bureau of Economic Research, was established in 1998 through a grant from the Social Security Administration. The Center's mission is to produce first-class research and forge a strong link between the academic community and decision-makers in the public and private sectors around an issue of critical importance to the nation's future. To achieve this mission, the Center sponsors a wide variety of research projects, transmits new findings to a broad audience, trains new scholars, and broadens access to valuable data sources.

\author{
Center for Retirement Research at Boston College \\ Hovey House \\ 140 Commonwealth Avenue \\ Chestnut Hill, MA 02467 \\ phone: 617-552-1762 fax: 617-552-0191 \\ e-mail: crr@bc.edu \\ crr.bc.edu
}

Affiliated Institutions:

The Brookings Institution

Massachusetts Institute of Technology

Syracuse University

Urban Institute 


\section{TABLE OF CONTENTS}

$\begin{array}{ll}\text { 1. Introduction } & \text { Page } 4\end{array}$

2. Survey Instrument and Design Page 5

$\begin{array}{ll}\text { 3. Data Cleaning and Quality } & \text { Page } 6\end{array}$

4. Statistical Analysis for Data Quality Page 10

5. Comparing Health and Demographic Characteristics with Previous Studies Page 11

6. Conclusions and Future Directions Page 14

7. References Page 16

\section{ASSOCIATED PAPERS}

1. $\quad$ Coe, Norma B. and April Yanyuan Wu. 2012. "Financial Well-Being of Residents in Seniors Housing and Care Communities: Evidence from the Residents Financial Survey." Working Paper 2011-7. Chestnut Hill, MA: Center for Retirement Research at Boston College.

2. Coe, Norma B. and April Yanyuan Wu. 2012. "Costs and Concerns Among Residents in Seniors Housing and Care Communities: Evidence from the Residents Financial Survey." Working Paper 2011-8. Chestnut Hill, MA: Center for Retirement Research at Boston College.

3. Coe, Norma B. and April Yanyuan Wu. 2012. "Geographic Mobility Among Residents in Seniors Housing and Care Communities: Evidence From the Residents Financial Survey.” Working Paper 2011-9. Chestnut Hill, MA: Center for Retirement Research at Boston College. 


\section{Introduction}

With the leading edge of the baby boom generation reaching retirement age, decisionmakers need a comprehensive understanding of their social, economic, and health characteristics - both in terms of resources and needs - in order to adopt effective public policies and private services to meet the needs of an aging population. One area of particular importance is their need for housing and long-term care services. A variety of options is available to meet these needs, including independent living (IL) and assisted living (AL) residences. ${ }^{1}$

Previous research has examined various aspects of the individuals who use these seniors' housing and care communities. In the late 1990s, the National Investment Center for the Seniors Housing \& Care Industry (NIC) sponsored survey research on the economic status of residents of AL communities. This research found that AL residents had significantly lower incomes than were reported in other industry-sponsored surveys, suggesting that other payment sources - such as asset liquidation and financial assistance from family members - could be important in covering the costs of care. More recently, Coe and Boyle (2012) used three existing, nationally representative surveys to compare the economic circumstances of the elderly based on their living arrangements: in private residences, in ALs, in ILs, and in continuing care retirement communities (CCRCs). Their study concludes that while we can learn from nationally representative surveys, they have significant limitations in addressing questions concerning the financial security of residents for three main reasons: (1) it is difficult to consistently identify individuals in senior care communities across the surveys; (2) the sample sizes are very limited for those you can identify, making longitudinal analysis difficult; and (3) the wealth data are insufficient to paint a reliable picture of the economic status of residents of these communities.

To fully understand the current and future economic situation of this population, we designed and conducted a new survey, the Residents Financial Survey (RFS), with assistance from ProMatura Group, LLC (ProMatura), to obtain a current economic profile of individuals living in ALs and ILs. This survey gathered information on the income and assets at the time of the survey (2011), as well as retrospective information concerning living arrangements, care provision, and financial gifts given.

\footnotetext{
${ }^{1}$ Nursing homes and continuing care retirement communities - which include independent living care segments are also important providers of housing and care, but outside the scope of this research.
} 
This paper provides an overview of the survey instrument and design, and details the data-quality analysis undertaken. Further, this paper provides descriptive statistics of the sample and compares it to other available surveys of the same population. We conclude that the data quality is high and quite reliable, and the survey contains a wealth of information about the economic well-being of seniors living in IL and AL communities.

\section{Survey Instrument and Design}

The Residents Financial Survey (RFS) was designed to measure the assets and incomes of individuals in freestanding ILs, freestanding ALs, and communities that offer both IL and AL arrangements. With assistance from ProMatura, we fielded a pilot survey in March 2011, which led to 47 completed surveys. To help ensure better participation, ProMatura reached out to individual communities and corporate offices to secure their support. Surveys were mailed to the staff of the 283 communities that agreed to participate, who then distributed them to the residents. The response rate was almost 56 percent at the community level (158 communities).

The questionnaire changed slightly between the pilot and the final survey. Two questions were added to the final survey; one question was reworded and shortened to make it easier to understand; and a "none of the above" option was added to three questions to help differentiate non-response from not having the item in question. The final survey was mailed between June 9 and July 29, 2011, and can be found in the Appendix. The 10,845 surveys mailed to IL residents, yielded 1,309 responses (12 percent response rate); and 14,146 to AL residents, yielded 1,261 responses (9 percent) - for a 10.2 percent combined response rate. While these response rates are low, they are typical for surveys of individuals in these communities. For example, the Income Confirmation Study, a survey of AL residents, had an overall response rate of 19 percent including returned surveys due to individuals passing or moving away, which is a 7.6 percent response rate for completed surveys. Importantly, we received more surveys than our initial target of 1,000 responses per IL and per AL, ensuring sufficient sample size for statistical analyses for each residence type. We tested for differences between the pilot and the final survey and found very few; thus, we combined the samples and used the full 2,617 responses. $^{2}$

\footnotetext{
${ }^{2}$ Pilot survey respondents were slightly more likely to skip more questions, even when taking the fact that "none-ofthe-above" answer was not available to them for three questions. They were also more likely to fill out the survey
} 
The RFS questionnaire is designed to build on existing data and broaden the range of information covered. When possible, we used pre-tested questions from existing surveys to help in comparing our results with nationally representative surveys. However, due to the average age and potential health limitations of the population, some question simplification was necessary. In the survey, we defined terms such as "current income," "community type," "longterm care insurance," and "net worth." We also allowed many questions to have an "other: please specify" option, so that individuals could include income/assets from sources by the names they are used to but which did not correlate exactly with those on our list. We then used this free-form answer information to place the income/assets into consistent categories. The next section discusses in detail the data evaluation process, including item non-response, outliers, skip patterns, re-coding of "other" responses, and internal consistency checks.

There are 477 individuals, or about 18 percent of the sample, living in ILs; 880 (34 percent) living in ALs; and 1,260 (more than 48 percent) living in communities that offer both IL and AL arrangements (with 32.6 percent in the IL portion and 15.5 percent in the AL portion).

\section{Data Cleaning and Quality}

\section{2a. Item non-response}

As an incentive to participate in the survey, individuals were eligible to enter a lottery for a $\$ 100$ cash prize. However, to maintain individual confidentiality, the lottery drawings were mailed to a different address; it is possible that a person could enter the lottery without actually mailing in the survey. ${ }^{3}$ This makes it less likely that individuals would not take the survey seriously just to enter the lottery drawing. However, given the age and the health status of the target populations, we need to undertake extensive testing to determine whether item nonresponse or data outliers are random - essentially white noise that can be ignored - or correlated with other characteristics of the individual, thus requiring corrections or potentially dropping the individual from the survey results.

Surveys were complete, for the most part, and responding individuals did not seem to suffer from question fatigue. Despite the length - 41 questions on seven pages (four double-

with the help of others. Based on the final survey responses, we re-coded missing values to questions 34 and 35 as none-of-the-above, but kept the missing responses to question 37 because it was not clear from the final survey whether the missing responses really indicated none-of-the-above responses.

${ }^{3}$ It actually seems that the reverse is true. There were a total of 2,318 lottery entries and 2,617 surveys received. The lottery drawing was held September 14, 2011, and the 20 winners were notified via telephone. 
sided) - only 24 people did not answer a single question on the last page. The first page of the survey was on the back of the first page of the pamphlet, and 2 percent of the sample missed this page. However, the most-skipped page (7) was skipped by only 4 percent of the sample, and no one skipped all of the back pages. Importantly, only 4 percent skipped the entire income section (V), which was the most-skipped section, and 2 percent skipped the entire asset section (VI).

Overall, item non-response was minimal. The most-skipped question, taking into account the acceptable skip pattern, was 23b, with 76 non-responses. The least-skipped question was 41, with 25 not answering. The most questions skipped by any individual, accounting for the skip pattern, was 37. And 31 percent of the respondents answered every question they should have answered. Figure 1 illustrates the number of questions skipped within the sample.

\section{2b. Outliers}

Another concern is outliers. The primary concern is in questions 23, 23b, and 39 for fillin dollar amounts. ${ }^{4}$ There was one outlier for question 23 concerning the monthly cost of the residence: it was more than 1.5 times the next highest reported amount, and almost 7.5 times the next highest amount reported for the same residence, given the type of care received and the number of people the charge was for. This was corrected by dropping a zero from the reported amount, which brings it in-line with fees reported by the community and fees reported by others within the community.

The other outliers are not obviously due to reporting error. For question 39, the top recorded value is almost twice the second-largest value, but there is a long right tail to the distribution of responses, so it is more difficult to assess if these outliers are due to reporting errors or true variation in the sample. Question 23b also has a long right tail, so while the highest value is more than 45 times the median, conditional on reporting additional services, it is only 1.1 times the next highest value. Therefore we conducted no additional data trimming or editing.

\footnotetext{
4 Outliers are also of concern for questions 25, 31, and 33, which are also fill-in monthly dollar amounts. However, since we also have a categorical question about total monthly income (question 36) as well as needs-based income from government sources, we have built-in check-points for questions 31 and 33 . We can also check question 25 , the amount paid towards regular expenses by other source than income, with questions 23 and 23b (monthly costs), and question 24 (how much of the monthly costs are met with regular income). Discussion of the cleaning of these questions is in section 5, internal consistency.
} 


\section{2c. Skip Patterns}

Skip patterns were built into the survey and indicated at the end of the selected answer. For example, after indicating that all daily living expenses were covered by current income (answer 1 to question 24), individuals were prompted to skip question 25 (concerning what other resources they used to cover these expenses) and move to question 26. However, because this was a paper survey and not a computer-assisted personal interview (CAPI), the skip patterns were not always followed. The skip pattern that most people did not follow was question 23a to question 23b, where 25 percent of the respondents skipped 23b when they should not have. The skip pattern followed most closely was question 13 to question 14, where only 2 percent of the respondents incorrectly answered the second question. There are also a few cases where people should have skipped a question but did not. The most frequent case of this "reverse skip" pattern is between questions 24 and 25, where 54 individuals answered the follow-up question when they did not need to.

\section{2d. Recoding "other/specify source" answers}

For many of the income and asset questions, we included the ability for the respondent to answer "other" and fill-in the specific income/assets they were referring to. This method revealed that individuals were using different classification systems than we had originally intended. For example, in question 25, some individuals responded that they were using an inheritance to pay for regular expenses - we would have categorized this as spending down current assets/savings. Table 1 indicates how we classified the "other" responses for questions 25, 35, and 37.

In addition, the fill-in responses in the "other" categories often informed us on other questions. For example, many people indicated in question 25 that long-term care (LTC) insurance helped pay for their current care. Thus, we edited answers to question 26 about LTC insurance accordingly. Fill-ins on question 25 also indicated Medicaid coverage, housing subsidies, and other government assistance programs, which we used to re-code these variables in question 35. Answers to the "other" category of income from federal or state governments indicated receipt of Social Security, federal pensions, and government bonds. While these were not the means-tested programs we intended to elicit with this question, we used these answers to double-check the answers to questions 29, 32, and 34. Finally, fill-in answers to question 37 
were used to check the answers concerning Social Security receipt, pensions, and LTC insurance coverage.

Moreover, respondents were asked to list all the reasons they think that they will move out of the current community within the next 12 months (question 21). We have categorized the open-ended answers to the most important reason into five categories: financial, health, unsatisfactory service, family and other reasons. This classification is detailed at the end of Table 1.

\section{2e. Internal Consistency}

Including questions on specific types of income and total income and specific types of assets and total net worth provide a way to check for internally consistent answers. For example, if an individual reports receiving \$1,200 in Social Security benefit income per month (question 31) and \$2,000 in pension or annuity income per month (question 33), we expect the individual to report that he or she has at least $\$ 3,200$ in total monthly income. Not following the skip pattern can also become a problem if answers are not internally consistent, i.e., someone indicates that all of his or her expenses are covered by current income in question 24 and indicates that he or she is using other assets to pay regular expenses in question 25.

We created variables to indicate when individuals were internally inconsistent. Fortynine people state that they received more money from Social Security (question 31), pensions (question 33), and income from other sources (question 34), than they report as their total income (question 36). Ninety-six individuals report that their current monthly bills (question 23 and question 23b) exceed their current income, yet state that they pay all their bills with their current income (question 24). Thirty-two respondents report high income (greater than $\$ 2,500$ per month) and report getting needs-based government assistance. Seventy-one people stated an extremely large value for their monthly bill for the community (question 23) - both in terms of their self-report compared to others in the same community (top 10 percent of reported fees) and compared to the community-reported fees (the difference between their monthly bill and maximum fees reported by the community was more than 30 percent of the maximum fee reported by their community). ${ }^{5}$

\footnotetext{
${ }^{5}$ The fee information was provided by matching respondents to the NIC Map database. Monthly fees were reported for studio, one-bedroom, and two-bedroom apartments.
} 
An additional 81 people stated an extremely small value for their monthly bill - both in terms of their self-report compared to others in the same community (bottom 10 percent) and compared to the community-reported fees (the difference between their monthly bill and minimum fees reported by the community) - was more than 30 percent of the minimum fee reported by their community. In addition, they did not report getting any financial assistance from the government. This could be due to family members receiving bills directly from the community, and the resident being unaware of these payments. See Overview of Assisted Living (2006) for more detail.

\section{Statistical Analysis for Data Quality}

We conducted regression analysis to test if item non-responses, section non-responses, page non-responses, outlier responses, and internally inconsistent responses are predictable using the other information available in the dataset. We were primarily concerned that some individuals were not reliable in their answers, either through inconsistencies or non-response. We created an index variable that counted the number of missing or "wrong” answers, as defined above. On average, almost three questions per respondent were either missing or considered questionable, but it varies between 0 and 37. There are not significant differences among the four types of respondents surveyed, those living in freestanding ILs (ILs), freestanding AL (ALs), IL residents in IL/AL, and AL residents in IL/AL). We tested to see if other factors could predict the quality of the survey answers. Respondents who filled out the survey themselves with no assistance had, on average, 1.5 additional problematic answers. This is not surprising given the age of the population surveyed. However, once the data are segmented by whether the respondent received help or not, virtually nothing predicted unreliable answers. While regression analysis shows that non-response does not relate to the quality of the survey answers, we further tested to see if individuals who missed a significant portion of questions were not reliable in their answers. We find that individuals who missed 15 questions or more (78 individuals, or less than 3 percent of the total sample) still provided reasonable answers to the questions of health and demographic characteristics, and the questions related to costs, income and assets. Their answers are very unlikely to fall into the category of outliers (at most 4 percent in question 23) or to be internally inconsistent (less than 1 percent provided questionable answers). We also conducted the same analysis on individuals who missed over 25 questions 
(only 15 individuals) and found that the quality of their answers is not a concern. Therefore, we have maintained the full sample of 2,617 respondents. We have re-coded answers that are questionable based on our internal consistency checks and report the percent of respondents who did not answer each particular question.

\section{Comparing Health and Demographic Characteristics with Previous Studies}

Table 2 presents the RFS sample’s health and demographic characteristics, separate by living arrangement. We tested to see if respondents could be pooled across freestanding AL, freestanding IL, or communities offering both, and found significant differences based on community type. Therefore, all of the statistics presented below are separated by freestanding IL, freestanding AL, IL residents in combined IL/AL communities, and AL residents in combined IL/AL communities. We also report item non-response and the percent of questionable answers as separate categories for each variable of interest. ${ }^{6}$

The average age of our sample is just over 86, with no significant differences across four types of living arrangements. The age distribution is slightly skewed to the right, with the median respondent being 87 years old. The age differences between the men and women are significant, however, with the women being older. Compared to earlier work, our sample is significantly older. ${ }^{7}$ The average age at which our respondents moved into their current community is 83.3 years old, with a median age of 84.4.

About one-quarter of the respondents living in freestanding ALs were men, with slightly higher representation in the other community types (31 percent for the AL portion of IL/ALs; 29 percent for ILs; and 35 percent for the IL portion of IL/ALs.). While this might seem low, the RFS has higher male representation for ALs than previous work. ${ }^{8}$ The proportion of men in ILs is comparable to the samples studied in Coe and Boyle (2012).

These residents are predominantly Caucasian, with more than 92 percent self-identifying as such. Almost 3 percent of the freestanding IL respondents are African-American, compared

\footnotetext{
${ }^{6}$ In the tables presented in the paper, we include non-response and questionable answers in the percentages so the reader has the full information. Appendix Table 1 presents the descriptive statistics percentages re-calibrated as a percent of those who answered correctly, instead of the percent of people in the survey, so comparison across the types of communities is easier for the reader.

${ }^{7}$ Coe and Boyle (2012), the Independent Living Report, ALFA (1998), and NIC (1998) all had average ages of 8085.

${ }^{8}$ See NIC (1998), ALFA (1998), and Coe and Boyle (2012).
} 
to less than 1 percent from the other community types. Even adjusting for the regional composition of our sample, Hispanics and African-Americans are underrepresented in these communities, compared to the U.S. 65-plus population of about 19 percent. $^{9}$

Marital status varies among the communities. Less than 10 percent of residents in freestanding ALs are currently married, and 72 percent are widowed. Respondents in the other community types are much more likely to still be married (16 percent for the AL portion of IL/ALs; 13 percent for ILs; and 20 percent for the IL portion of IL/ALs). The marital pattern for ILs and the IL portion of IL/ALs is comparable to that reported by Coe and Boyle (2012). It is lower than that reported in the Independent Living Report (about 35 percent), but that is not surprising considering their focus was on new entrants and included CCRCs in the sample. For freestanding ALs and the AL portion of IL/ALs, our sample is much less likely to be married than the 20-percent marriage rate among AL residents found in Coe and Boyle (2012).

Consistent with the existing literature, we find that the educational achievement of residents in these four types of communities is higher than the U.S. as a whole. Specifically, 41 percent of residents in the IL portion of the IL/ALs had a college degree, which is higher than residents in freestanding ILs (28 percent), freestanding ALs (23 percent), and the AL portion of the IL/ALs (29 percent). Only 20 percent of the overall U.S. 65-plus population has a college degree. The RFS sample exhibits slightly lower educational attainment than found in the Independent Living Report. When we compare recent movers to longer-term residents within the RFS, we find similar levels of education among recent movers (33 percent with a college degree versus 30 percent of the longer-term residents), which suggests that the difference with the Independent Living Report is driven by the inclusion of CCRCs being in the sample, which apparently attract an even more educated clientele.

Overall, the average number of residents’ living children among our sample is almost 2.5, with little variation between the types of living arrangements. These numbers are comparable to Coe and Boyle (2012), but slightly lower than the U.S. 65-plus population of almost $3 .^{10}$

One-quarter to one-third of the respondents report themselves to be in very good or excellent health compared to their peers. Figure 2 explores this further, showing that 6-9 percent

\footnotetext{
${ }^{9}$ Authors' calculations using the 2010 Current Population Survey (CPS). The fraction of non-white in the CPS is about 17 percent for over-85 population, suggesting that the low minority representation is not just an age-effect. ${ }^{10}$ Author's calculations of the Survey of Consumer Finances (2007). The average number of living children of the over-85 population is 2.5 .
} 
rated their health as excellent, which is lower than reported in the Independent Living Report (11 percent for ILs and 14 percent for the IL portion of IL/AL). However, the RFS sample is healthier than that reported in the Independent Living Report when we focus on recent movers. About one-third of respondents in freestanding ILs rated their health as very good, 37 percent as good, 21 percent as fair, and 2 percent as poor. In contrast, self-reported health is relatively worse for the residents in ALs and the AL portion of IL/AL, with about 9 percent and 7 percent reporting poor health, respectively. We also find that more than 50 percent of respondents rate their current health as "Much better now," "Somewhat better now," or "About the same” as compared to two years ago. Further, there does not appear to be a relationship between health changes and the length of time living in the current community. This suggests that individuals are not experiencing rapid or continuous health declines.

While the survey spanned the continental U.S., our responses show regional concentration. Forty percent of the entire sample is located in the West, with another 30 percent located in the South. However, the regional variation depends on the type of community. Over 60 percent of the freestanding IL sample is located in the Midwest, with very few observations coming from the South or the North. Conversely, over 20 percent of the AL sample (both freestanding and combined) is located in the North. Despite the geographic variation in the community types, we see very little difference in the sample characteristics by community, such as race, age, education, and number of children, which do have regional variation in the population as a whole.

Finally, we examined who actually answered the survey. Figure 3 shows that two-thirds of the respondents completed the survey, either by themselves or with the help of others. Family members participated in the completion of 38 percent of the surveys, staff assisted in the completion of 2 percent, and friends participated in completion of 1 percent. In many instances, more than one person (resident and family or staff member) participated in the completion of the survey. Not surprisingly, being in very good or excellent health is positively correlated with the resident filling in the survey on their own. The percent of the residents participating in completing their own surveys is comparable (almost 60 percent) to those reported in NIC (1998). However, what does differ is others’ involvement. Our respondents' families were much more involved than in previous work (only 20 percent of family members were involved in NIC (1998)) instead of relying as heavily on staff assistance (40 percent). We also examined the 
characteristics of family members who participated in the completion of the survey. More than half of the family members completing the surveys are daughters; more than one-quarter are sons; 6 percent are spouses; and the rest are extended family, including brother/brother-in-law, sister/sister-in-law, cousin, niece/nephew, and grandchildren.

It is not surprising that residents in ILs (both freestanding and combined IL/AL) are more likely to complete or participate in the completion of the surveys: 91 percent of residents who live in the IL portion of ILs/ALs and 72 percent in freestanding ILs participated in completing the surveys, compared to only 46 percent in freestanding ALs and 60 percent in the AL portion of IL/ALs. In contrast, 61 percent of residents who live in freestanding ALs have their family members participate in the completion of the surveys. The corresponding numbers for residents are 44 percent in the AL portion of IL/ALs, 32 percent in freestanding ILs, and 15 percent in the IL portion of IL/ALs.

\section{Conclusions and Future Directions}

After extensive study of item non-responses, skipped questions, outliers, and internal inconsistencies, we are confident that the data quality is high. We have concluded that for the most part the responses are reasonable, and when they are not, they seem to be "noise" and not a sign of systematic reporting errors. Given the time, effort, and cost of the survey, this is reassuring.

The Residents Financial Survey indicates that residents in the four types of care communities examined (freestanding ILs, freestanding ALs, IL portion and AL portions of IL/AL communities) are over 80 years old, on average, and predominately white, female, and college educated. The survey achieved regional variation, although part of this variation is driven by the different types of communities surveyed. Many of the respondents are widows, but unlike previous work, we also pick up a relatively high percentage of intact couples. Individuals tend to rate their health relatively favorably to others in their age group. Accordingly, they also seem more willing and able to undertake the survey responses, either by themselves or with assistance of family or staff.

This survey is a new and important contribution to the research community. There are many research questions that can be addressed with this new dataset. In a series of companion papers, we explore the costs of the communities and concerns residents have about paying for 
these costs, the financial well-being of residents, and their geographic mobility patterns (Coe and Wu 2012a-2012c). However, there are many other potential uses for this new data source. For example, future work could include examining the role of family, in paying for care and provision of care, and how that relates to the past, current, and future living arrangements. 


\section{References}

Assisted Living Federation of America (ALFA). 1998. "The Assisted Living Industry: An Overview - 1998”. Fairfax, VA: Price Waterhouse and ALFA.

Coe, Norma B. and Melissa Boyle. 2012. "The Asset and Income Profile of Residents in Seniors Care Communities.” Research on Aging, forthcoming.

Coe, Norma B. and April Yanyuan Wu. 2012a. "Financial Well-being of Residents in Seniors Housing and Care Communities: Evidence from the Residents Financial Survey.” Working Paper 2012-7. Chestnut Hill, MA: Center for Retirement Research at Boston College.

Coe, Norma B. and April Yanyuan Wu. 2012b. "Costs and Concerns among Residents in Seniors Housing and Care Communities: Evidence from the Residents financial survey." Working Paper 2012-8. Chestnut Hill, MA: Center for Retirement Research at Boston College.

Coe, Norma B. and April Yanyuan Wu. 2012c. “Geographic Mobility among Residents in Seniors Housing and Care Communities: Evidence from the Residents financial survey.” Working Paper 2012-9. Chestnut Hill, MA: Center for Retirement Research at Boston College.

“Income Confirmation Study of Assisted Living Residents and the Age 75+ Population.” 1998. Annapolis, MD: National Investment Center for the Seniors Housing \& Care Industry.

National Investment Center for the Seniors Housing \& Care Industry. 1998. "National Survey of Assisted Living Residents: Who is the Customer?” Annapolis, MD.

“Overview of Assisted Living.” 2006. Washington, DC: American Association of Homes and Services for the Aging, American Seniors Housing Association, National Association for Assisted Living; Alexandria, VA: Assisted Living Federation of America; and Annapolis, MD: National Investment Center for the Seniors Housing \& Care Industry.

“The Independent Living Report.” 2009. Washington, DC: American Seniors Housing Association. 


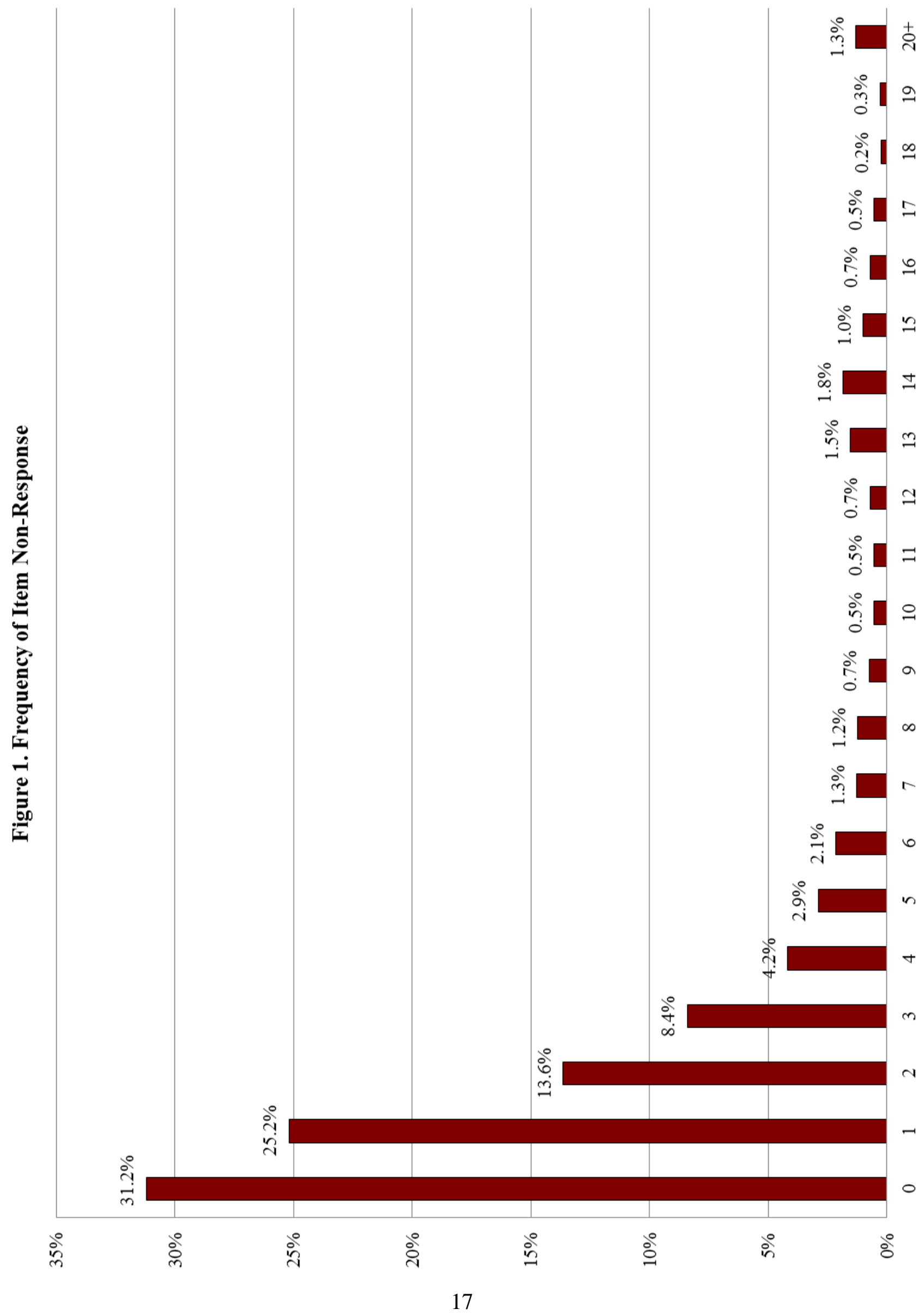



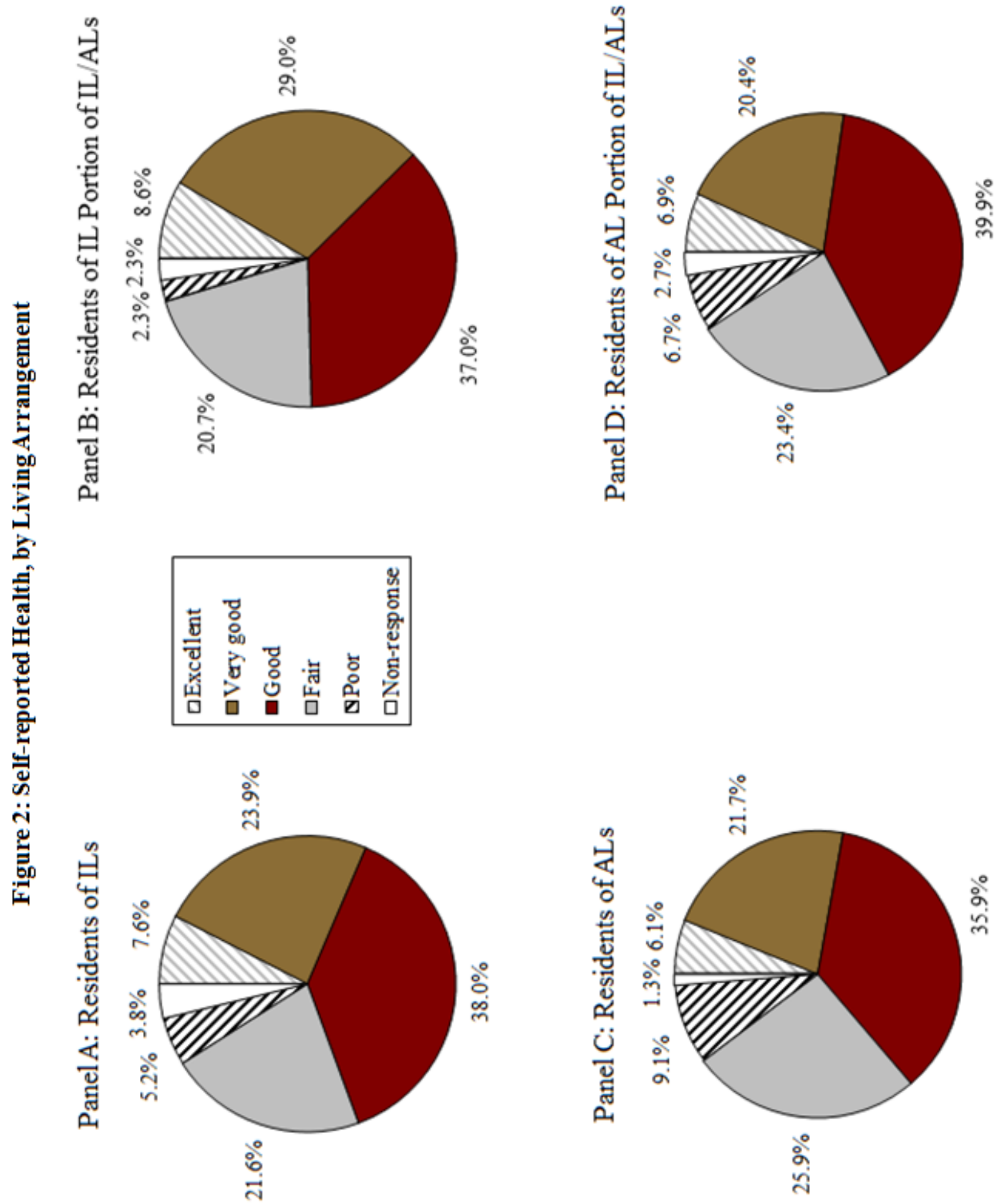
Figure 3. Who Completed the Survey

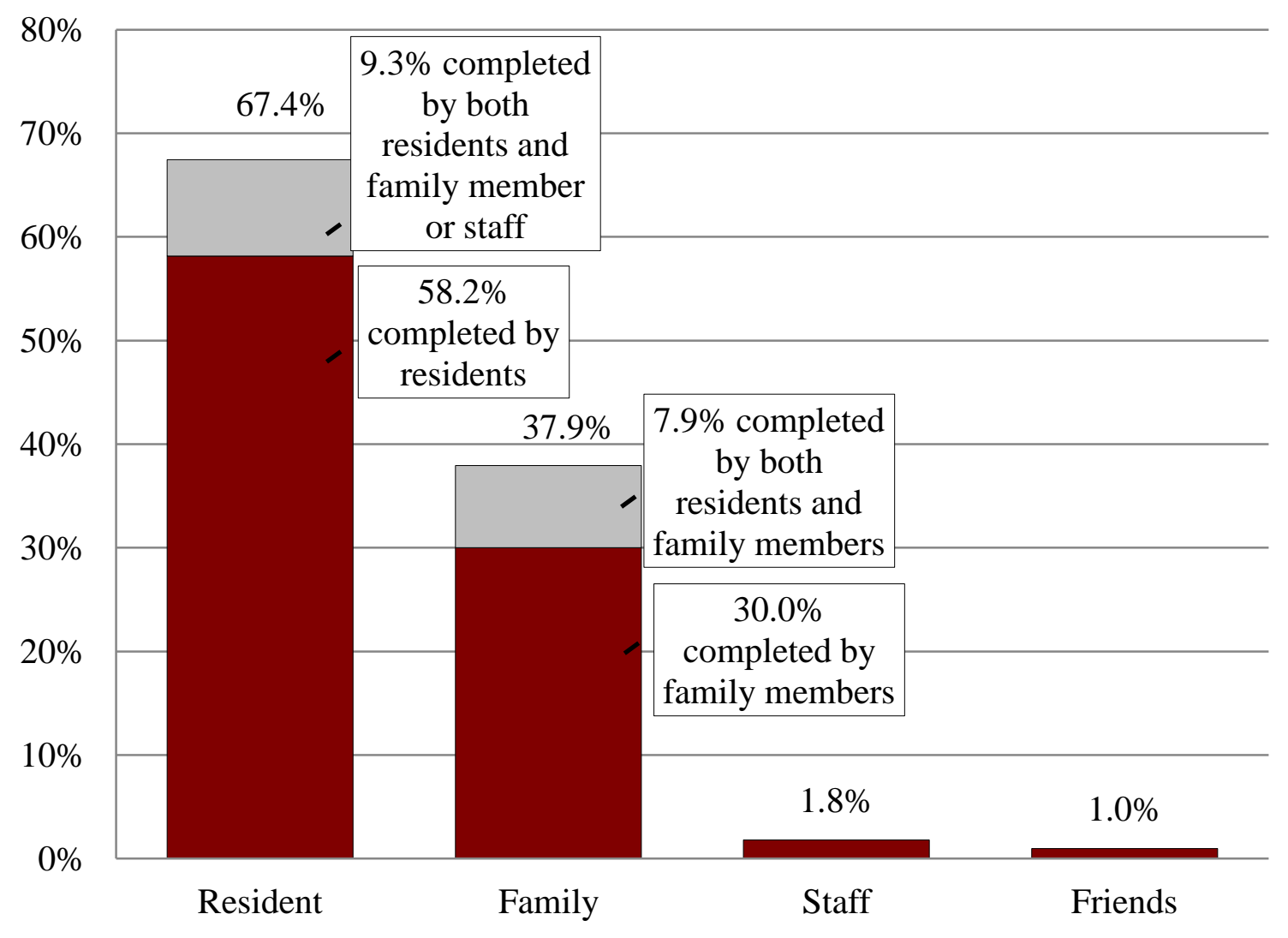


Table 1. Reclassifying “Other” Responses

Question 25: Other sources that pay regular expenses

\begin{tabular}{|c|c|c|}
\hline $\begin{array}{l}\text { Spending Down } \\
\text { Saving/Assets }\end{array}$ & My children/family & $\begin{array}{l}\text { Other sources of } \\
\text { income }\end{array}$ \\
\hline Inheritance & Friend & $\overline{\text { LTC insurance }}$ \\
\hline Bonds & & Medicaid \\
\hline CDs & & Medicare \\
\hline Capital Gains & & Low-rent housing \\
\hline Stocks & & Federal/state Aid \\
\hline Trust/Trust Fund & & VA benefits \\
\hline IRA & & Renting home \\
\hline Investments/Mutual & & Alimony \\
\hline Funds & & Social Security \\
\hline Retirement Funds & & Annuity/ Retirement \\
\hline Sale of house & & income/ Pension \\
\hline Sold land (owner & & Disability \\
\hline finance) & & Business income/farm \\
\hline Credit card & & Employment \\
\hline Equity line of credit & & \\
\hline
\end{tabular}

on home

Question 35: Other sources of government support

\begin{tabular}{|c|c|c|}
\hline HUD Rental & Disability benefits & Other \\
\hline \multicolumn{3}{|l|}{ Assistance } \\
\hline MI Housing & 100 percent disability & Agency for Living \\
\hline Allowance & VA & Aid for Assisted \\
\hline MISHDA Rent & Disability & Living \\
\hline Assistance & Medicare Disability & American Eldercare \\
\hline \multirow[t]{5}{*}{ Section 8 Housing } & SS Disability & Heart and Home \\
\hline & Temp. total disability & Hospice \\
\hline & Workers' & Low income \\
\hline & Compensation & assistance \\
\hline & & Navy Mutual Aid \\
\hline
\end{tabular}

Question 37: Other assets

Brokerage/stock/
bonds/mutual fund
$\$ 52,00015$ year note.
Investment-low risk
Investments
Money from sale of
car
Money from sale of
house

401(k), IRA, SEP or Trusts KEOGH

Annuities and IRA

Annuity fund and retirement equity fund Deferred compensation

2nd retirement income

\author{
A House, Property \\ or Land \\ Contract on mobile \\ home \\ House-being sold \\ Vacation home \\ Time shares
}


Table 1 (cont'd). Reclassifying “Other” Responses

Question 37: Other assets (cont'd)

Farm or business A car or other vehicles

Partnerships

2007 Kia paid for
1981 Ford Fairlane

2007 Kia paid for

\author{
Personal \\ Antique furniture \\ Personal property \\ Art work \\ Clothes and jewelry \\ Computer and Printer \\ Doll Collection \\ Furnishings/Furniture \\ Porcelain collectibles \\ Jewelry \\ Stamp and coin \\ collection
}

\author{
Other \\ Interest from private \\ loan \\ Leased mineral rights \\ Mortgage on \\ properties \\ Savings \\ Royalties \\ Gold/Gold pieces \\ Boat
}

Question 21: Primary reason for moving out

\begin{tabular}{|c|c|c|c|}
\hline Financial & & & \\
\hline “\$3295.00 per & “Expenses.” & “To save & "Rent is too high and unevenly \\
\hline month is pricy." & "Expensive" & money” & (unfairly) administered.” \\
\hline “Assets & “Finances” & “Too costly." & "Run out of money” \\
\hline depleting.” & “Financial & “Too & “This community does not accept \\
\hline "Becoming too & reasons.” & expensive” & Medicaid” \\
\hline expensive” & “Family runs out & “Too & "Need more affordable assisted care for \\
\hline “Better & of money to pay & expensive for & wife.” \\
\hline accommodation & fees.” & services & "No money left to pay for living \\
\hline at lower total & "I will run out of & needed.” & expenses" \\
\hline expense.” & money” & "Unable to & “No more money to pay.” \\
\hline “Can only & "If SS folds, not & continue & "Not enough money to pay for where I \\
\hline afford to stay a & enough income.” & paying.” & live.” \\
\hline $\begin{array}{l}\text { few more } \\
\text { months } "\end{array}$ & "If they keep & "Will run out & "Price goes up annually and I get no \\
\hline "Can own & "If they raise my & "Cost-they are & "Raise in fees." \\
\hline cheaper than & rent beyond my & raising fees & "Rate increases." \\
\hline this outrageous & ability to pay.” & almost \$2000.” & "Rent beyond my income” \\
\hline rent." & "Inability to sell & “Cost/Value” & "Cost, won't be able to afford it \\
\hline "Can't afford it" & home.” & “Excessive & anymore.” \\
\hline “Can't afford & "Increase in & increase of & "Cost too high." \\
\hline services.” & rent.” & fees.” & “Lack of financial support.” \\
\hline "Care paid for is & “Increase in & "Rent cost" & \\
\hline NOT being & rental fees and & "Rent is & \\
\hline provided.” & new fees for & beyond our & \\
\hline "Cost" & services formerly & income" & \\
\hline “Cost - Personal & provided.” & "Rent is too & \\
\hline service fee & "Increases are & high.” & \\
\hline increased at & above the cost of & "Lack of & \\
\hline least $15 \%$ this & living. New & money.” & \\
\hline year and & residents are & “Medical & \\
\hline additional & upgraded before & assistance too & \\
\hline
\end{tabular}




\section{Table 1 (cont'd). Reclassifying “Other” Responses}

Question 21: Primary reason for moving out (cont'd)

\begin{tabular}{|c|c|c|c|}
\hline$\underline{\text { Health }}$ & $\underline{\text { Service }}$ & $\underline{\text { Family }}$ & Other \\
\hline services needed. & old residents.” & expensive.” & \\
\hline Rent also & “Increasing costs & “Money” & \\
\hline increased 15\%.” & and declining & "Money- & \\
\hline "Cost increases" & service.” & taxes and & \\
\hline "Cost of Living & “Insufficient & insurance & \\
\hline at the & funds to remain & very costly.” & \\
\hline community.” & here.” & $\begin{array}{l}\text { "My } \\
\text { insurance } \\
\text { policy is } \\
\text { up." }\end{array}$ & \\
\hline “Age.” & “Food-not & "Family is in & “Can't adjust to apartment living.” \\
\hline “Alzheimer's & enough & Denver, & "Discrimination”" \\
\hline Progressing” & vegetables, too & Co.” & “Independent-not quite so.” \\
\hline “Alzheimer's- & much fish and & “Going to & "More disabled residents moving in.” \\
\hline need more & chicken.” & live with & "Lack of privacy and independence.” \\
\hline care.” & “Food.” & daughter.” & “May not need service offered here.” \\
\hline “Death” & "If some things & "Live closer & “Not appropriate placement.” \\
\hline “Declining & don't change.” & to family.” & \\
\hline mental health.” & "Lack of & “Moving & \\
\hline “Dementia.” & activities for & back home." & \\
\hline "Deteriorating & people in & “Moving & \\
\hline health & wheelchairs" & home.” & \\
\hline condition.” & "Lack of care” & "No family & \\
\hline "Deteriorating & “Lack of & here.” & \\
\hline health.” & $\begin{array}{l}\text { maintenance." } \\
\text { "Lack of staff and } \\
\text { staff } \\
\text { competence." }\end{array}$ & $\begin{array}{l}\text { "Return to } \\
\text { home state." }\end{array}$ & \\
\hline "Deteriorating & "Lack of staff and & “To be & "Not appropriate placement.” \\
\hline health.” & staff & closer to & “Not familiar with the area” \\
\hline "Existing brain & competence.” & children and & "People are much older and disabled." \\
\hline tumor.” & "Lots of & grandchildre & “Religious community” \\
\hline "Failing health." & scorpions in this & n.” & "Residents here are too old, only a few \\
\hline 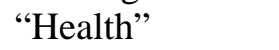 & apartment & “To be & close in age to me.” \\
\hline “Health doesn't & building." & closer to & "Residents here require various levels of \\
\hline warrant assisted & "Meal quality." & family” & care and many have physical and mental \\
\hline living anymore” & "More frequent & "To be near & challenges.” \\
\hline "Health & transportation to & daughter.” & “Think I can live alone.” \\
\hline improving.” & stores, & "To be near & “To be near VA Hospital” \\
\hline "Higher level of & community & family.” & “Too many mistakes.” "Too many moving \\
\hline assisted living & affairs, outings” & “To be near & in that should be in AL not IL due to \\
\hline required.” & “More skilled & my & physical/mental health concerns.” \\
\hline "I will be well & nurses.” & children.” & "Too many people who cannot converse \\
\hline and can return & "No meals" & "To be with & with each other.” \\
\hline to unassisted & “Noisy dogs” & family.” & "Too many residents need to be in assisted \\
\hline living.” & "Non-interest of & "Want to be & living." \\
\hline "If my health & management to & closer to & “Very unhappy.” \\
\hline
\end{tabular}




\section{Table 1 (cont'd). Reclassifying “Other” Responses}

Question 21: Primary reason for moving out (cont'd)

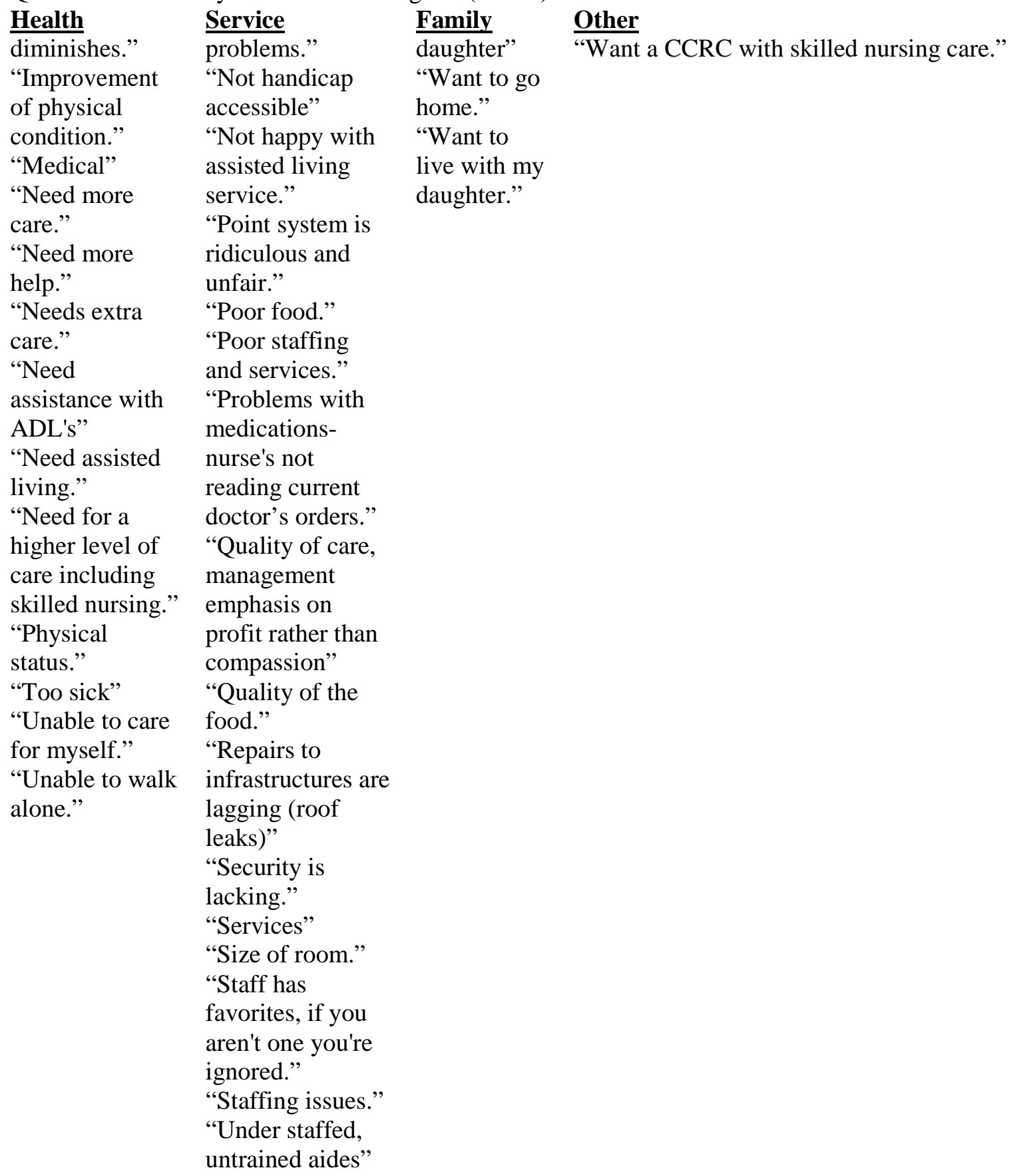

Health

diminishes.”

"Improvement

of physical

condition.”

"Medical"

"Need more

care."

"Need more

help."

"Needs extra

care."

"Need

assistance with

ADL's"

"Need assisted

living."

"Need for a

higher level of

care including

skilled nursing."

"Physical

status.”

"Too sick"

"Unable to care

for myself."

"Unable to walk alone.”

\section{Service}

problems."

"Not handicap

accessible"

"Not happy with

assisted living

service."

"Point system is

ridiculous and

unfair."

"Poor food."

"Poor staffing

and services."

"Problems with

medications-

nurse's not

reading current

doctor's orders."

"Quality of care, management

emphasis on

profit rather than

compassion"

"Quality of the

food."

"Repairs to

infrastructures are

lagging (roof

leaks)”

"Security is

lacking."

"Services"

"Size of room."

"Staff has

favorites, if you

aren't one you're

ignored.”

"Staffing issues."

"Under staffed,

untrained aides”

\section{Family Other}

daughter" "Want a CCRC with skilled nursing care."

"Want to go

home."

"Want to

live with my

daughter.” 
Table 2. Demographic and Health Characteristics of Residents

Freestanding Combined IL Freestanding Combined AL

$\underline{\text { IL }}$

Current age

Average age

Median age

Non-response

Age moved into current community

Average age

Median age

Non-response

Gender*

Male

Non-response

Race*

African-American

White

Non-response

Marital status*

Married

Widowed

Divorced

Non-response

Education*

Less than high

school

College educated

Non-response

Number of children

Average number of

children

Median number of

children

Non-response

Health*

Self-rated excellent

or very good

Non-response

Same/better

compared to two

years ago

Non-response
86.2

87.0

$7.3 \%$

82.6

83.7

$14.5 \%$

$28.5 \%$

4.2

$2.7 \%$

92.0

3.8

$13.2 \%$

66.9

9.9

3.6

$12.6 \%$

28.3

4.2

2.5

2.0

$8.0 \%$

$31.5 \%$

3.8

56.4

4.0
86.4

87.0

$5.2 \%$

83.4

83.9

$14.4 \%$

$34.7 \%$

2.9

$1.0 \%$

94.5

2.6

$20.1 \%$

67.5

5.9

2.3

$4.5 \%$

40.6

2.8

2.5

2.3

2.2

2.0

2.0

2.0

$9.6 \%$

$7.2 \%$

$4.9 \%$

7.7

11.5

$13.5 \%$

23.1

$10.6 \%$

29.1

3.0

1.6

$27.3 \%$

2.7

2.3

$27.8 \%$

1.3

51.3

53.2

1.5 
Table 2 (cont'd). Demographic and Health Characteristics of Residents

\section{Freestanding Combined IL Freestanding Combined AL \\ $\underline{\text { IL }} \quad \underline{\text { AL }}$}

Census region

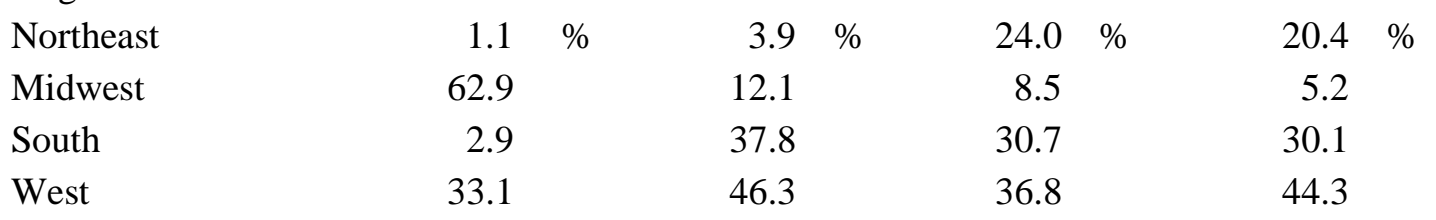

Who completed the survey (multiple answers possible)*

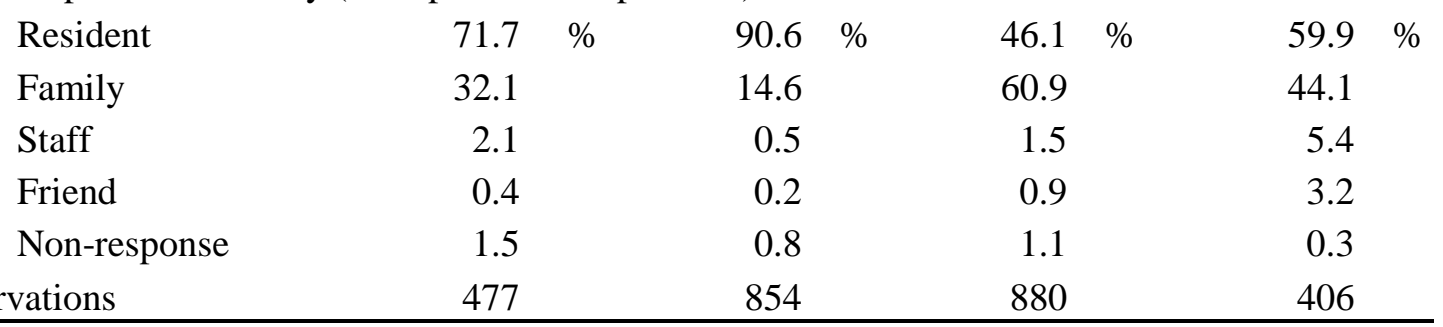

Source: Authors' calculations of the Residents Financial Survey.

*: See Appendix Table 1 for calculations of the percentages that treat non-response as missing observations. 


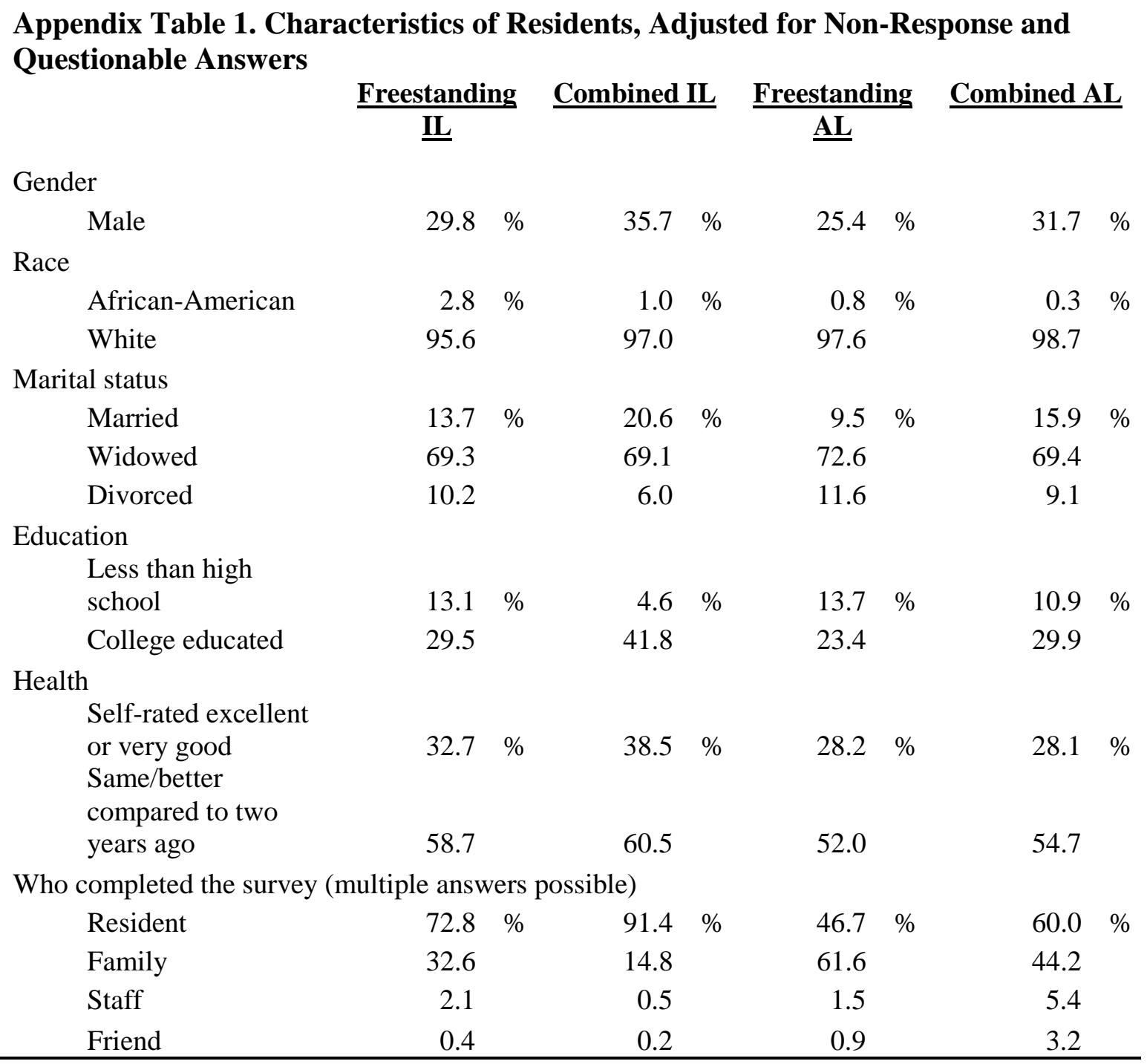

Source: Authors' calculations of the Residents Financial Survey. 
Appendix:

Survey Instrument 


\section{Consumer Finance Survey of Independent and Assisted Living Residents}

\section{Please help us improve.}

This survey is being conducted by the ProMatura Group on behalf of the National Investment Center for the Seniors Housing \& Care Industry (NIC). NIC helps community owners and operators learn about the customers they serve. We are being helped in the interpretation of the survey results by experts at the Center for Retirement Research at Boston College. The Center provides decision-makers in the public and private sectors with critical information to better understand the issues facing an aging population.

Topic of the Survey. As the title suggests, this survey asks you (resident and/or family members on behalf of a resident) to provide information about your income, expenses, investments, pensions, and just about everything dealing with your finances and how you pay for your residence and services at this community. We know this is a sensitive issue, but it is important for this industry to know the financial impact of communities, (such as the one in which you live), on you and your family. All questions are about the resident or his or her finances.

Your Survey is Anonymous. There is no place for you to put your name on the survey. We do not want or need to know who you are.

\section{Confidentiality Guarantee}

Because we are not capturing any personally identifying information from you and because your data will be put into a database with 1,999 other unidentified surveys, I give you my personal guarantee that your information cannot and will not be traced to you.

I guarantee that none of your information in this survey will be viewed by anyone except a data entry clerk at the ProMatura Group, LLC in Oxford, Mississippi (where you will mail the survey). I guarantee that no one at your community or any other location will see your information, ever.

We are sincerely grateful to you because this survey will be of enormous help for communities to provide better service and greater value.

Thank you, we are grateful to you for your help,

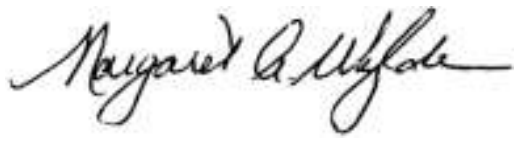

Margaret A. Wylde, Ph.D.

President, CEO, and Owner

ProMatura Group, LLC 


\section{All answers should relate to the resident.}

\section{SECTION I: DEMOGRAPHIC and HEALTH INFORMATION}

1. In what year were you born?

19

2. What is your gender?

$1 \square$ Male

2पFemale

3. What race/ethnicity do you consider yourself to be? (Please check all that apply)

$1 \square$ White

2 $\square$ Black/African American

$3 \square$ Hispanic

$4 \square$ Asian

$5 \square$ Other

4. What is the highest level of education you have completed? (Please check one)

$1 \square$ Grade school or less

$2 \square$ Some high school

$3 \square$ High school graduate or G.E.D. (Earned diploma)

$4 \square$ Some college or Associate Degree (2-year)

$5 \square$ College, graduate or professional degree (BA, BS, MA, Ph.D., M.D., etc.)

5. How many living children do you have?

6. What is your marital status? (Please check one)

$1 \square$ Married

2पWidowed............. In what year did your spouse die?

$3 \square$ Divorced

$4 \square$ Separated

$5 \square$ Single, never married

$6 \square$ Other

7. Compared to other people your age, would you say your health is: (Please check one)

$1 \square$ Excellent

$2 \square$ Very good

$3 \square$ Good

$4 \square$ Fair

$5 \square$ Poor

8. Compared to two years ago, how would you rate your current health? (Please check one)

$1 \square$ Much better now

$2 \square$ Somewhat better now

$3 \square$ About the same

$4 \square$ Somewhat worse now

$5 \square$ Much worse now

Call $800 \cdot 201 \cdot 1483$. Ask for Connie Hay.
Refer to the Consumer Finance Survey. 


\section{All answers should relate to the resident.}

\section{SECTION II: BEFORE MOVING TO THIS COMMUNITY}

9. Where did you live just before you moved to this community?

City: $\quad$ State: _ _ ZIP Code: $\square \square \square \square \square$

10. With whom did you live just before you moved to this community?

(Please check one)

$1 \square$ No one, I lived by myself

$2 \square$ I lived with only my spouse

$3 \square$ I lived with my spouse and others (Relationship?

$4 \square$ I lived with family other than a spouse (Relationship?

$5 \square$ I lived with someone other than family (Relationship?

11. Did you live in another community where residents must be at least 55 or 62 years of age at any time before you moved to this community?

$1 \square$ Yes

$2 \square$ No [Skip to question 13]

3ロDon't Know

12. In which type of age-qualified community did you live? (Please check one)

$1 \square$ Active Adult community: the community typically has amenities such as a club house, fitness center, swimming pool, etc. The services, if any are provided, are typically related to the upkeep of the facilities, maintenance of the roads, sidewalks, driveways and sometimes lawn/ landscaping services.

$2 \square$ Independent Living community (may be part of a community with a continuum of care, $\boldsymbol{C C R C ) : ~ T h e ~ f e e ~ t o ~ l i v e ~ i n ~ t h e ~ c o m m u n i t y ~ t y p i c a l l y ~ i n c l u d e s ~ a ~ d i n i n g ~ p r o g r a m , ~}$ housekeeping, and transportation services. The community typically provides various educational, entertainment, cultural, fitness, and wellness opportunities.

$3 \square$ Assisted Living community (may be part of a community with a continuum of care, CCRC): is one designed to assist residents with activities of daily living such as bathing, toileting, and dressing. Most communities also offer assistance with and/or reminders to take medication.

$4 \square$ Rehabilitation Center or Nursing Care Center: this type of residence may be where services are provided by licensed health care professionals such as nurses, nurse aides, and physical therapists.

13. During the six months before moving to this community, did anyone regularly assist you with any daily activities such as: shopping, preparing or providing meals, dressing, bathing, toileting, managing or taking your medications?

$1 \square$ Yes

$2 \square$ No [Skip to next page, question 15]

14. Who provided assistance to you? (Please check all that apply)

$1 \square$ Family and/or friends (either paid or unpaid).

$2 \square$ Individuals whose job it is to provide the services. 


\section{All answers should relate to the resident.}

SECTION III. THIS COMMUNITY - The Residential Property Where You Live Today

15. When did you move to this community?
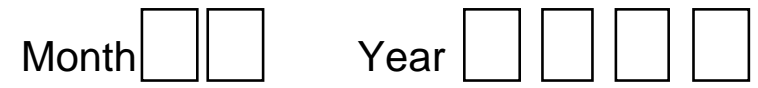

16. Where is your community located? ZIP Code

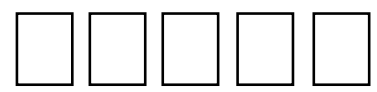

17. Is there a fund at your community that will pay for housing and services if a resident is unable to do so? (Please check one)

$1 \square$ Yes

$2 \square$ No

$3 \square$ I don't know

18. If you are married, do the two of you live in the same residence in the community, or live in separate locations? (Please check one.)

$1 \square$ Not applicable.

$2 \square$ We live together in the same residence.

$3 \square$ We live separately in different apartment/residences in this community.

$4 \square$ My spouse continues to live in our previous home.

$5 \square$ My spouse lives in a nursing home or medical center not in this community.

$6 \square$ Other. Please explain:

19. The community where I live now offers me good value for my money. (Please check one.)

$1 \square$ Strongly agree

$2 \square$ Agree

$3 \square$ Neutral

$4 \square$ Disagree

$5 \square$ Strongly disagree

20. Within the next 12 months, do you think you will move out of this community? By "out of this community," we mean that you will not live anywhere on the premises.

$1 \square$ Yes

$2 \square$ No [Skip to next page, question 23]

21. Please list all the reasons why you think you will move out of this community.

\begin{tabular}{l}
\hline Most important: \\
\hline Important: \\
\hline Less important: \\
\\
$1 \square$ To an apartment that does not include any services in the monthly fee. \\
2 $\square$ To another community similar to the one in which I am living currently. \\
$3 \square$ To a community that offers assisted living services. \\
$4 \square$ To a community that offers or nursing care. \\
$5 \square$ To my home. \\
$6 \square$ To the home of a family member (child, sibling, etc.). \\
$7 \square$ Other
\end{tabular}




\section{All answers should relate to the resident.}

\section{SECTION IV. FINANCING CURRENT RESIDENCE AND SERVICES}

23. Based on your most recent monthly bill, how much do you pay in total for your residence and all services you receive in this community?

$\$$ per month is for $1 \square$ One person

2םTwo people

23a.Do you pay any additional amount (not included in 23 above) to another agency such as a home health care agency and/or a person such as a "sitter," "care companion," or helper to provide services to you in your residence within the community?

$1 \square$ Yes

$2 \square$ No [Skip to question 24]

\begin{tabular}{|l|l|l|l|}
\hline $\begin{array}{l}\text { 23b. List the service you receive that is not included in } \\
\text { your monthly bill from the community in which } \\
\text { you live. }\end{array}$ & $\begin{array}{l}\text { Who provides the service } \\
\text { (agency or private individual)? } \\
\text { Please check all that apply. }\end{array}$ & $\begin{array}{l}\text { Typical total } \\
\text { amount paid per } \\
\text { month for service }\end{array}$ \\
\hline & $\square$ Agency & $\square$ Individual & \\
\hline & $\square$ Agency & $\square$ Individual & \\
\hline & $\square$ Agency & $\square$ Individual & \\
\hline
\end{tabular}

24. Which one of the following statements best describes how much you pay of the monthly fees at this community and your other regular expenses such as: groceries, dining out, gasoline, entertainment, clothing, beautician fees, etc? Do not include one-time or unusual expenditures.

Current Income: includes Social Security, pensions, rental income from real estate, business income, income from interest and dividends, and income from government assistance.

(Please check one.)

$1 \square$ All of these expenses are covered by my current income. [Skip to question 26]

$2 \square$ Most of these expenses are covered by my current income, with the rest paid by my savings, assets, children, or other sources.

$3 \square$ Some of these expenses are covered by my current income, with the rest paid by my savings, assets, children, or other sources.

$4 \square$ None of these expenses are covered by my current income, and all are paid by my savings, assets, children, or other sources.

25. Which of the sources, in addition to your income, are used to pay your regular expenses? (Please check all that apply)

$1 \square$ Spending down my savings and/or my assets

$2 \square$ My children/family

$3 \square$ Other sources

Monthly amount, if applicable

Please specify:

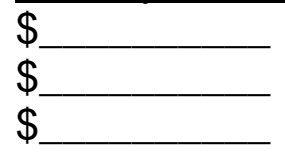




\section{All answers should relate to the resident.}

26. Which of the sources, in addition to your income, are used to pay your regular expenses Do you own a private long-term care insurance policy that pays for your stay in a nursing home, assisted living, or home care? This does not include funds from VA Benefits, Medicaid, Medicare, or any other government program. This refers only to a long-term care insurance policy that you purchased.

$1 \square$ Yes

$2 \square$ No

3Don't know

27. Relative to my ability to afford the fees at this community, I have...

(Please choose one)

$1 \square$ No concern

$2 \square$ Some concern

$3 \square$ Considerable concern

28. What is it about your financial situation that causes you to have this opinion?

\section{SECTION V: INCOME}

29. Do you (or your spouse) receive Social Security payments?

$1 \square$ Yes

$2 \square$ No [Skip to 32]

30. At what age did you begin receiving Social Security?

31. About how much in total did you (and your spouse) receive from Social Security last month? $\$$

32. Do you (or your spouse) receive regular income from a pension or annuity from a former employer or the military?

$1 \square$ Yes

$2 \square$ No [Skip to 34]

33. About how much in total did you (and your spouse) receive from these pensions/annuities last month? \$

34. Please identify if you receive regular income from any of the following sources. (Please check all sources of income that you receive).

$1 \square$ Interest income from bank accounts, CDs, money market accounts

$2 \square$ Interest or dividend income from stocks, mutual funds, bonds or other investments

$3 \square$ Rental income from real estate

$4 \square$ Income from a business or farm

$5 \square$ Income from a trust fund

$6 \square$ Income from a reverse mortgage

$7 \square$ None of the above 


\section{All answers should relate to the resident.}

35. Please identify if you receive any income or assistance from any of these government agencies. (Please check all sources of assistance that your receive).

$1 \square$ Veteran's Administration Aid and Attendance Pension

2 $\square$ Medicaid or a state needs-based health insurance

3 $\square$ Supplementary Security Income (SSI)

$4 \square$ Food stamps

5HUD Rental Assistance Program

6ᄆ Any income from any other government sources.

Please specify:

$7 \square$ None of the above

36. Please indicate the approximate total amount of income you receive each month from all sources. (Please check only one box.)

$1 \square$ Less than $\$ 850$ monthly

$2 \square$ Between $\$ 850$ and $\$ 1,199$

$3 \square$ Between $\$ 1,200$ and $\$ 1,499$

$4 \square$ Between $\$ 1,500$ and $\$ 1,999$

$5 \square$ Between $\$ 2,000$ and $\$ 2,499$

$6 \square$ Between $\$ 2,500$ and $\$ 2,999$

$7 \square$ Between $\$ 3,000$ and $\$ 3,499$

$8 \square$ Over $\$ 3,500$ per month

\section{SECTION VI: ASSETS}

37. Please check each of the following types of assets that you own.

(Please check all that apply)

$1 \square$ A checking, savings, Certificate of Deposit, or Money Market account

$2 \square$ A brokerage, stocks, bonds, or mutual fund account

$3 \square$ A 401(k), IRA, SEP, or KEOGH

$4 \square$ A trust

$5 \square$ A house, property, or land

$6 \square$ Part or all of a farm or business

$7 \square$ A car or any other vehicles

$8 \square$ Any additional assets. Please describe:

$9 \square$ None of the above

38. Taking into account all the financial holdings of your household, including the value of any other properties you own, and subtracting any money that you owe, which of the following categories best represents your total net worth?

(Please check only one)

$1 \square$ Under $\$ 50,000$

$2 \square \$ 50,000$ to $\$ 100,000$

$3 \square \$ 100,000$ to $\$ 299,999$

$4 \square \$ 300,000$ to $\$ 499,999$

$5 \square \$ 500,000$ to $\$ 749,999$

$6 \square \$ 750,000$ to $\$ 999,999$

$7 \square \$ 1,000,000$ to $\$ 1,999,999$

$8 \square \$ 2,000,000$ or more

Call $800 \cdot 201 \cdot 1483$. Ask for Connie Hay. Refer to the Consumer Finance Survey. 


\section{All answers should relate to the resident.}

39. In the last five years (since 2006), have you given a monetary gift in a single year of more than $\$ 10,000$ to a person or entity such as heirs, trusts, or charitable institutions (please exclude college tuition or weddings)?

$1 \square$ Yes What is the approximate total value of financial gifts given in the past 5 years $\$$

$2 \square$ No

40. Do you (or your spouse, if applicable) on a regular basis (such as bi-weekly or monthly) give financial help totaling $\$ 500$ or more to any of your relatives?

$1 \square$ Yes

$2 \square$ No

41. Who completed this survey?

$1 \square$ Resident

$2 \square$ Resident with assistance from

$3 \square$ Family member (relationship to resident)

(relationship of person assisting you)

$4 \square$ Other (Title and relationship to resident)

\section{We thank you for your trust, time, thoughtfulness, and generous spirit!}

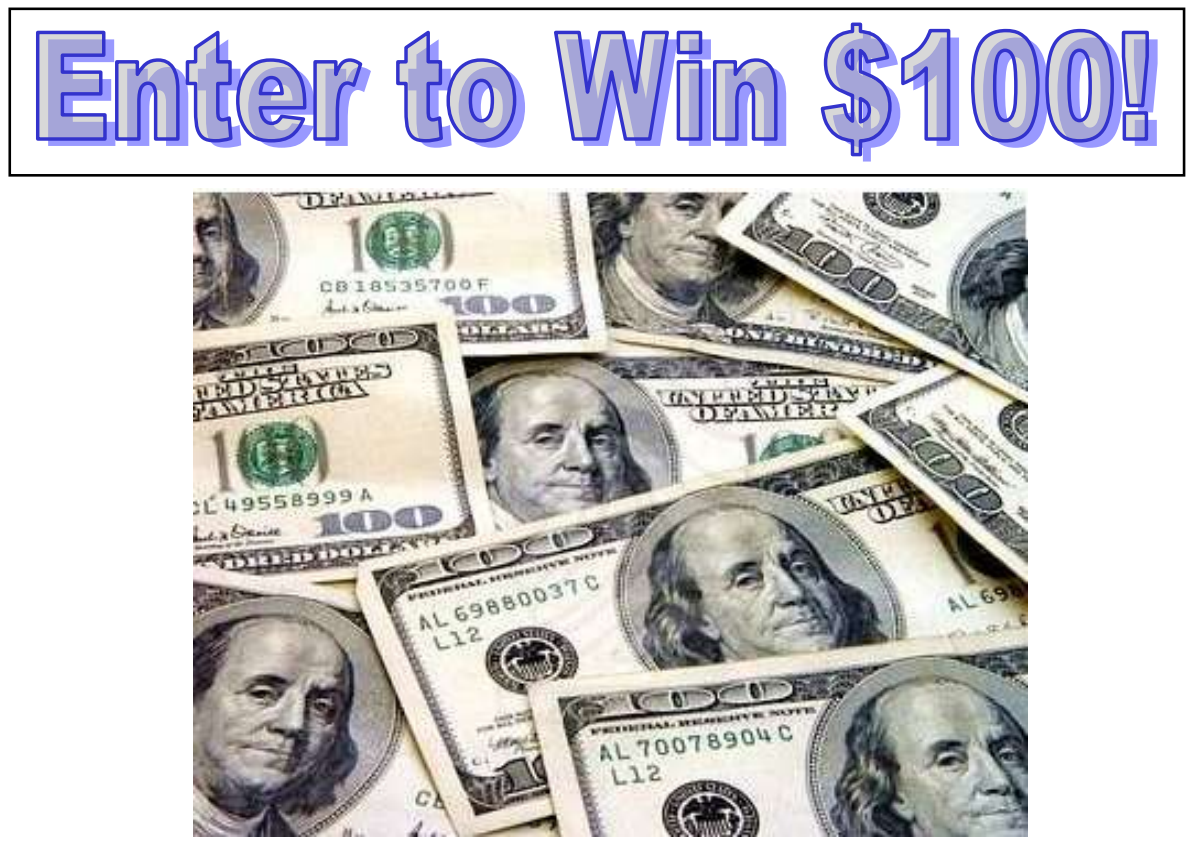

Please be sure to send in your entry for your chance to win $\$ 100$. It's the small card with the accompanying envelope. The National Investment Center for the Seniors Housing \& Care Industry (NIC) will draw the names of 20 people from the enrollment cards that are submitted. Your odds of winning $\$ 100$ are approximately 1 out of 100 . For a drawing, those are very good odds.

Send your Drawing Entry card in the envelope to the National Investment Center in Annapolis, Maryland. Send your completed survey in the large postage paid business reply envelope to the ProMatura Group in Oxford, Mississippi.

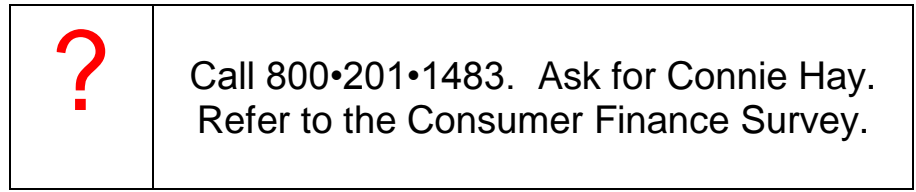

We guarantee your confidentiality. Thank you again for participating in the survey. 


\section{RECENT WORKING PAPERS FROM THE CENTER FOR RETIREMENT RESEARCH AT BOSTON COLLEGE}

Social Security Claiming: Trends and Business Cycle Effects

Owen Haaga and Richard W. Johnson, February 2012

Economic Consequences of the Great Recession: Evidence from the Panel Study of Income Dynamics

Barry Bosworth, February 2012

The Changing Causes and Consequences of Not Working Before Age 62

Barbara A. Butrica and Nadia Karamcheva, February 2012

The Impact of Temporary Assistance Programs on Disability Rolls and Re-Employment Stephan Lindner and Austin Nichols, January 2012

Understanding the Growth in Federal Disability Programs: Who Are the Marginal Beneficiaries, and How Much Do They Cost?

Adele Kirk, January 2012

What Explains State Variation in SSDI Application Rates?

Norma B. Coe, Kelly Haverstick, Alicia H. Munnell, Anthony Webb, December 2011

How Do Subjective Mortality Beliefs Affect the Value of Social Security and the Optimal Claiming Age?

Wei Sun and Anthony Webb, November 2011

How Does the Personal Income Tax Affect the Progressivity of OASI Benefits?

Norma B. Coe, Zhenya Karamcheva, Richard Kopcke, Alicia H. Munnell, November 2011

The Pension Protection Act of 2006 and Diversification of Employer Stock in Defined Contribution Plans

Gary V. Engelhardt, November 2011

Prescription Drug Insurance Coverage, Drug Utilization, and Cost-Related NonAdherence: Evidence from the Medicare Part D Expansion

Gary V. Engelhardt, November 2011

Social Security on Auto-Pilot: International Experience with Automatic Stabilizer Mechanisms

Barry Bosworth and R. Kent Weaver, November 2011

All working papers are available on the Center for Retirement Research website (http://crr.bc.edu) and can be requested by e-mail (crr@bc.edu) or phone (617-552-1762). 